pathogenicity to different hosts, investigation of the responsible mechanisms of variation and the background genetics of these organisms is essential.

The vigorous discussions during the symposium will undoubtedly influence programmes of work already in progress and shape the framework of much of the future planning. This was its purpose and the indications are that it was eminently successful. Equally, certainly it encouraged our hope for significant extension of the already successful biological control of plant diseasos.
The benefit and encouragement from this symposium was expressed in a resolution, endorsed unanimously by the participants: "that a second symposium, along somewhat similar lines, should be held possibly in Britain, in five years time". A steering committee was selected at the symposium to investigate this possibility.

The proceedings of the symposium, including papers, session reviews and general discussion will be published in full. The volume should serve as a valuable reference text in this field.
N. T. Flentue

\title{
TEACHING OF BIOLOGY
}

$\mathrm{A}^{\mathrm{N}}$ $\mathrm{N}$ interim report of the Royal Society-Institute of Biology Joint Committee on the Teaching of Biology has recently been issued.

The Committee has made itself acquainted with a large amount of work being carried out by numerous bodies at present interesting themselves in the improvement of biological teaching.

It feels strongly that biology should not be taught solely as a vocational training, but should take its proper place as a powerful instrument of education for life in the modern world. It has taken particular note of the Biology Section of the Nuffield Foundation's Science Teaching project and its work in devising teaching aids for the age-range 11-16.

Biology in the Sixth Form: University Entrance. The Committee has been informed of the views of professors of botany and zoology on desirable qualifications for entrance to university biology departments. A majority of each expresses a preference for a combination of biology and chemistry at the Advanced Level of the General Certificate of Education with supporting qualifica. tions in physics and mathematics. A willingness to accept other combinations has been indicated, and the more traditional one of botany, zoology and chemistry is preferred by a minority. The Committee agrees that means should be devised to secure the maintenance of a minority stream of 'natural history' biologists through the universities.

Biology Syllabuses. In accordance with the trend already noted many examining bodies are at present producing or revising syllabuses for biology as a single subject at advanced level. The Committee notes with regret that no co-ordination has been attempted between the different examining bodies and that needlessly wide divergencies are arising which will create serious difficulties for sixth-form biology teaching

Relations between Sixth Form and University Biology Teaching. The connexion between school and university teaching is the weakest link in the present chain. It requires careful study with a close co-ordination of the views of those engaged on both school and university aspects of the problem. The Committee proposes to set up a small study-group to obtain the necessary data which should enable it to make proposals within a reasonable time for a rational solution of this critical problem.
Teachers' Refresher Courses. Individual university biology departments, usually with the co-operation of departments of education, have provided valuable help to school teachers in the form of vacation courses of about a week's duration. These have been well supported and much appreciated; but it is thought that not more than 10 per cent of the demand is at present met. To satisfy the demand fully would place an unmanageable burden on the university departments. It has been suggested that university and technical college departments should be asked to provide short (one-day or week-end) courses for teachers from schools in their own neighbourhoods. A sampling inquiry to about a dozen departments has shown much willingness on their part to co-operate. The Committee therefore proposes to circularize biology departments in universities and technical colleges throughout the country with the hope of promoting a nation-wide network of such help for teachers.

Curriculum Studies. A panel of the Joint Committee met and discussed the American Biological Sciences Curriculum Study courses with a number of educationists who have recently visited American schools.

As a result of their discussions it is not felt possible to adapt these courses to British conditions, both because of the considerable differences of suitable biological material, and because of the great divergences of the American and British educational systems into which the biology has to be fitted. The publications associated with the courses are being sent to Britain, and may have their uses as teachers' source books (see Nature, 197, 4; 1963). It does not seem necessary either to encourage or to discourage their entry.

A pamphlet setting out the aims of the Biological Sciences Curriculum Study project and its relevance to British conditions is being prepared and will be published in the Institute of Biology Journal.

Pamphlets on Current Topics. The Committee has welcomed a proposal from the Institute of Biology to publish on a subscription basis a series of booklets on subjects of biological interest yet falling outside the normal text-book range or up-to-dateness. It has undertaken to advise on the choice of topics and a number of titles are under consideration.

\section{OBITUARIES}

\section{Prof. F. W. Jane}

The sudden death of Prof. Frank W. Jane on May 6 in Ibadan where, with the permission of the Council of Royal Holloway College, he was acting as temporary professor and head of the Department of Botany in the University of Ibadan, leaves a gap which is going to be very hard to fill. Indeed, because he was such a modest man, it is only now that one realizes in how many different spheres he had achieved distinction and how widely he will be missed.

First and foremost he was a botanist and naturalist. Much of his early research work, while he was at University College as assistant lecturer, lecturer and then reader, dealt with freshwater algae. The results were published between 1937 and 1944 in such journals as the Transactions of the Hertfordshire Natural History Society (1937, 1938, 